\title{
Distribution of Earthworms at Different Habitats in Tangail, Bangladesh and Significantly Impacts on Soil pH, Organic Carbonand Nitrogen
}

\author{
Iqbal Bahar', Md. Sarwar Jahan², Md. Redwanur Rahman ${ }^{2, *}$ \\ ${ }^{1}$ Department of Environmental Science and Resource Management, Mawlana Bhashani Science and Technology University, Tangail, \\ Bangladesh \\ ${ }^{2}$ Institute of Environmental Science, University of Rajshahi, Rajshahi, Bangladesh
}

Email address:

ibahar75@yahoo.com (I. Bahar), msjahan@lycos.com (M.S. Jahan), redwan_rahman@lycos.com (M. R. Rahman)

\section{To cite this article:}

Iqbal Bahar, Md. Sarwar Jahan, Md. Redwanur Rahman. Distribution of Earthworms at Different Habitats in Tangail, Bangladesh and Significantly Impacts on Soil pH, Organic Carbonand Nitrogen. American Journal of Life Sciences. Vol. 3, No. 3, 2015, pp. 238-246. doi: $10.11648 /$ j.ajls.20150303.26

\begin{abstract}
Distribution of Earthworms at Different Habitats in Tangail District Significantly Impacts on Soil pH, Organic Carbon and Nitrogen. The earthworms were studied on habitat base. Two orders of class Oligochaeta of phylum Annelida: five families, nine genera include fifteen species. The recorded species are Drawida limella Gates 1934, Drawid anepalensis Michaelsen 1907, Glyphidrilus tuberosus Stephenson 1916, Amynthas alexandri Beddard 1900, Lampito mauritii Kinberg 1866, Metaphire houlleti Perrier 1872, Metaphire posthuma Vaillant 1868, Perionyx excavatus Perrier 1872, Perionyx horai Stephenson 1924, Perionyx modestus Stephenson 1922, Perionyx simlaensis Michaelsen 1907, Dichogaster modiglianii Rosa 1896, Dichogaster saliens Beddard 1893, Eutyphoeus gigas Stephenson 1917, Eutyphoeus orientalis Beddard 1883. The Highest number (11) of species was observed in water body adjacent habitat. The lowest number (03) of species was observed in steep habitat. The highest number (10) of species was observed in Gopalpur and Bhuapur upazila and the lowest number (04) of species was observed in Madhupur upazila. The studied parameters of soil were $\mathrm{pH}$, organic carbon (OC) and nitrogen (N).The $\mathrm{pH}$ value of soil in the study area was slightly acidic but very close to the neutral status. Organic carbon status of the soil favors the distribution and abundance of earthworm that influence the soil nutrients and fertility. Nitrogen status was recorded under low level marked $(0.075 \%)$ in eleven (11) upazila out of twelve (12). The scenario of the soil nutrients OC and N are not up to the mark in the study area. Positive correlation was found between $\mathrm{pH}$ value of soil and earthworm species distribution in different habitats. Organic carbon is positively correlated with earthworm distribution. Nitrogen is positively correlated with organic carbon. These correlations establish that soil fertility is an integrated task where the participation of earthworm plays positive role.
\end{abstract}

Keywords: Earthworm, Habitats, Soil pH, Organic Carbon, Nitrogen, Bangladesh

\section{Introduction}

Earthworm belongs to one of the most important invertebrate groups of the class Oligochaeta under the phylum Annelida and is well known for its contribution to soil formation and wide spread global distribution. [1] described the distribution of some earthworm species that are dispersed over a wide range of geographically remote localities. Many workers studied the habitat preference of various earthworm species [2-4]. The presence of a species in a particular habitat and its absence from other habitats shows the species-specific distribution of earthworms in different pedoecosystems [5]. The distribution of earthworm mainly depends on the physico-chemical characteristics of the soil. The life of earthworm is very strongly influenced by the soil reaction and they can live only in slightly acidic and neutral soil. They play role to neutralize the soil. The food they ingest, pass through the gut with calcium carbonate particles coated mucus substance by calciferous glands and possibly influence $\mathrm{pH}$ control [6].Soil moisture, organic carbon and nitrogen are significantly correlated with the distribution of the earthworms [7]. Earthworms are widely distributed throughout the world and their population contributes $80 \%$ of the total biomass of the soil ecosystem [8]. 
Organic matter content of soil is an indicator of its fertility and productivity. A good soil should have an organic matter content of more than 3\%. But in Bangladesh, most soils have less than $1.5 \%$, some soils have less than $1 \%$ organic matter [9]. Earthworms have a major role in the breakdown of organic matter. By releasing and recycling the organic matter and nutrients, they are playing important role in soil fertility [10-12] reported analytical data of 29 soil series; all had the nitrogen content below the critical level. The earthworms derive their nourishment from the microorganisms that grow upon the organic wastes, at the same time they promote further microbial activity in the wastes. The casts are much more microbial active than the wastes the earthworms consume. Earthworms promote to release of nitrogenous nutrients and solubilization of phosphate [13].Earthworm is an important biological resource that has a tremendous potential in agro-ecosystems because they significantly affect soil physical structures and organic matter dynamics, and promote plant growth [14]. The casting activity of earthworms shows positive impact on physical and chemical properties of soil. Earthworms consume the organic materials and process the elements as essential nutrients for plant growth [15]. Earthworms represent biological strategies of nutrient cycling in soil and contribute in maintaining soil fertility. The habitat preference of various earthworm species significantly impacts on soil $\mathrm{pH}$, organic carbon and nitrogen.

\section{Materials and Methods}

The study of earthworm distribution was covered at different habitats (homestead garden, cultivable land, fallow land, steep and water body) in different upazilas of Tangail district, Bangladesh. Soilphysico-chemical parameters: $\mathrm{pH}$, organic carbon and nitrogen status were studied in relation with the presence of earthworm. Samples were collected from one square meter marked area. The number of each earthworm species was recorded per square meter area. The distribution of earthworm in the study area was calculated habitat based in different upazila of Tangail district. The map of the study area is shown below-

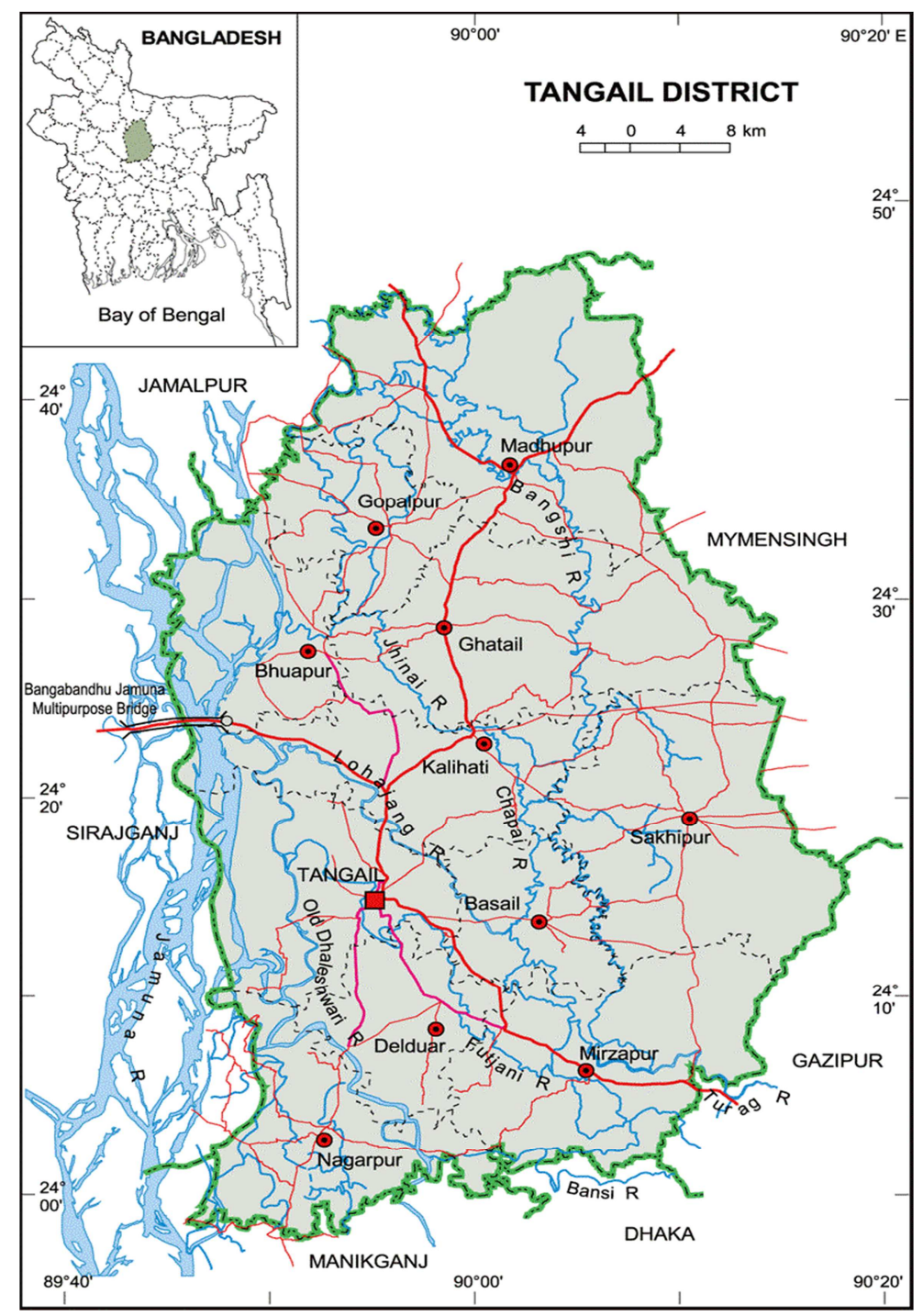

The indicated box in the map means sampling site of the localities

Map. 1. The map of the study area. 


\subsection{Collection of Earthworm and Taxonomic Study}

The earthworms were collected following [16] hand sorting method. The quadrates were explored with a spade at the depth of $0-10 \mathrm{~cm}, 10-20 \mathrm{~cm}$ and $20-30 \mathrm{~cm}$ and so on step wise to collect earthworms. Digging and hand sorting method as well as formalin expulsion method, suggested by [17] were also applied for the exploration of earthworms. For taxonomic studies earthworms were collected from diverse ecological niches of the study area. The collected earthworms were identified to the species level with the help of monographs of [18-21].

\subsection{Collection of Soil Samples, Preparation and Analysis}

The soil samples were collected from the study area to study the status of the soil $\mathrm{pH}, \mathrm{OC}$, and $\mathrm{N}$ in response with earthworms' presence in different habitats. From every upazila five sampling spots were selected as homestead garden, cultivable land, fallow land, steep and water body. The soil samples were collected from the topsoil in poly bag. From each sampling spot $500 \mathrm{~g}$ soil was taken as sample. The soil samples were prepared in the laboratory of Institute of Environmental Science (IES), University of Rajshahi for analysis. The soil samples were placed on thin and clean piece of paper and left until air-dried. Visible roots and plant fragments were removed from the soil sample and discarded. The soil was dried in the laboratory in room temperature. After drying the different size of soil samples were grinded with mortar and pestle and then they were passed through the $2 \mathrm{~mm}$ sieve. Before grinding the soil samples the mortar and pestle were cleaned properly every time. During the grinding and processing of soil samples, each sample was kept separated and covered to avoid contamination of the samples. The ground soil sample was transferred to a plastic container with screw cap. The container was properly labeled and kept for the experiment. The weight of the soil samples' was taken to make solution for the physico-chemical parameters test according to the experimental methods. Analytical methodssoil, water, plant material, fertilizer by Lief Petersen adopted from APHA (American Public Health Association) were used to analyze the chemical parameters of the soil.

\section{Results}

The presence of a species in a particular habitat and its absence from other habitats shows the species-specific distribution of earthworms. The distribution of earthworm enhances the biological diversity, soil environment and fertility. This soil fauna is occurred in different habitats and different localities (upazila) with the natural support and furnishes the environment. There are 15 species of earthworms recorded in the study area. $D$. limellais found in two habitats: cultivable land and fallow land in sufficient moist condition (sometimes in dyke) in Delduar, Mirzapur, Gopalpur, Dhanbari and Bhuapur upazila. D. nepalensis is found in cultivable land and fallow land in rich vegetation area in Delduar, Sakhipur, Ghatail, Tangail, Basail, Dhanbari and Bhuapur upazila. G. tuberosusis occurred in water bodyand cultivable land, submerged soil and irrigated paddy fields in sufficient organic matter and moisture in Delduar, Nagorpur, Mirzapur, Madhupur and Bhuapur upazila. $P$. corethrurus is collected from water body (sewage effluent, household drainage) fallow land and steep in the jungle in the sub surface of the soil in Delduar, Nagorpur, Kalihati, Madhupur and Bhuapur upazila. A. alexandri is found in the habitat of homestead garden and fallow land in Nagorpur, Mirzapur, Sakhipur, Tangail, Basail, Gopalpur and Dhanbari upazila. L. mauritiiis recorded from homestead garden and adjacent to water body (household drainage, garbage heap, organic matter rich soil) in Nagorpur, Tangail, Kalihati, Madhupur, and Bhuapur upazila. M. houlleti is recorded from the habitat of water body (adjacent to household drainage, sewage effluent drainage, under logs, sometimes garden and organic matter rich moist soil in Delduar, Sakhipur, Tangail, Basail and Gopalpurupzila. M. posthuma is recorded from homestead garden, water body and fallow land (sewerage effluent, household drainage, near to dampy places) in Delduar, Nagorpur, Sakhipur, Ghatail, Basail, Kalihati and Gopalpur upazila.

$P$. excavatus is recorded from $\mathrm{W}$. body (household drainage), fallow land in organic matter rich sufficient moist soil, and epigic in Nagorpur, Mirzapur, Tangail, Basail, Kalihati, Gopalpur, Dhanbari and Bhuapur upazila. The species is suitable for vermiculture and vermicomposting. $P$. horaiis recorded from water body and its adjacent areas and household drainage, dyke of irrigation drain in cultivable land in Nagorpur, Tangail, Kalihati and Gopalpur upazila. $P$. modestus is recorded from moist soil of homestead garden (adjacent to household drainage, garbage heap) and water body in the adjacent areas (sewage effluent drainage) in Nagorpur, Tangail, Basail, Kalihati and Gopalpur upazila. $P$. simlaensis is recorded from moist soil of homestead garden (adjacent to household drainage, garbage heap) and water body and its adjacent areas (sewage effluent drainage) in Sakhipur, Tangail, Gopalpur, Dhanbari and Bhuapur upazila. D. modiglianii is recorded from water body in the adjacent areas, cultivable land (irrigated paddy field in highly moist condition), in organic debris in Nagorpur, Mirzapur, Basail and Dhanbari upazila. D. saliensis recorded from adjacent area of water body and household drainage, fallow land in highly moist condition or clay in rich organic matter soil in Mirzapur, Ghatail, Basail, Gopalpur, Madhupur, and Bhuapur upazila. E. gigasis recorded from fallow land and steep habitat above the flood level in moist condition in Delduar, Sakhipur, Ghatail, Gopalpur, Dhanbari and Bhuapur upazila. E. orientalis is recorded from fallow land, steep habitat (embankment, adjacent to garbage heap, and household drainage) in Sakhipur, Ghatail, Dhanbari and Bhuapur upazila. 


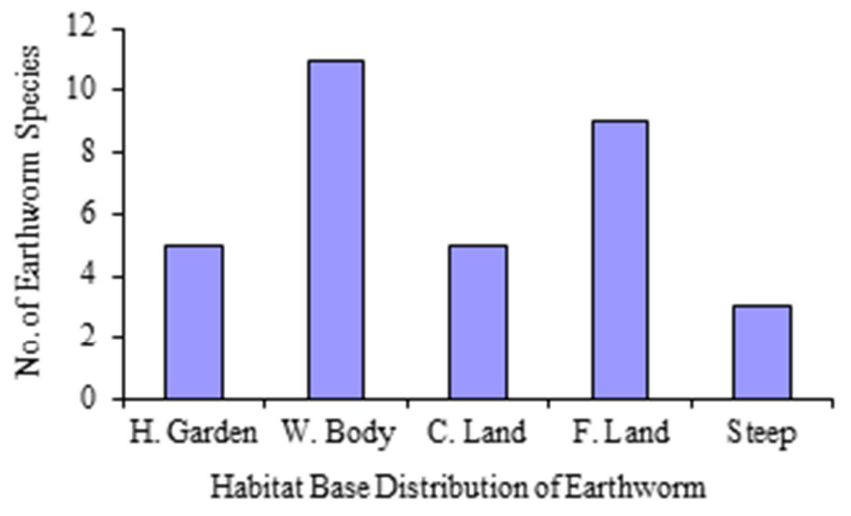

Note: $\mathrm{H}=$ Homestead, $\mathrm{W}=$ Water, $\mathrm{C}=$ Cultivated, Fallow)

Figure 1. Distribution of earthworm species (habitat base).

The highest number of species is observed in water body habitat, 11 in number. Water body certainly covers the optimum moisture content, organic matter and other influencing factors. The lowest number of species is observed in steep habitat, 03 in number. Same number of species that is 5 is observed in homestead garden habitat and cultivable land habitat. 9 species are observed in fallow land habitat. The distribution of earthworm species in the cultivable land is not enough.

The highest number of species distribution is observed in Gopalpur and Bhuapur upazila and the lowest number of species distribution is observed in Madhupur upazila. Seven species are recorded from Delduar, nine species are recorded from Nagorpur, six species are recorded from Mirzapur, seven species are recorded from Sakhipur, five species are recorded from Ghatail, eight species are recorded from Tangail, seven species are recorded from Basail, seven species are recorded from Kalihati, ten species are recorded from Gopalpur, four specie are recorded from Madhupur, eight species are recorded from Dhanbari and ten species are recorded from Bhuapur upazila in the study area. Figure 2 represents the upazila base distribution of earthworm species in number.

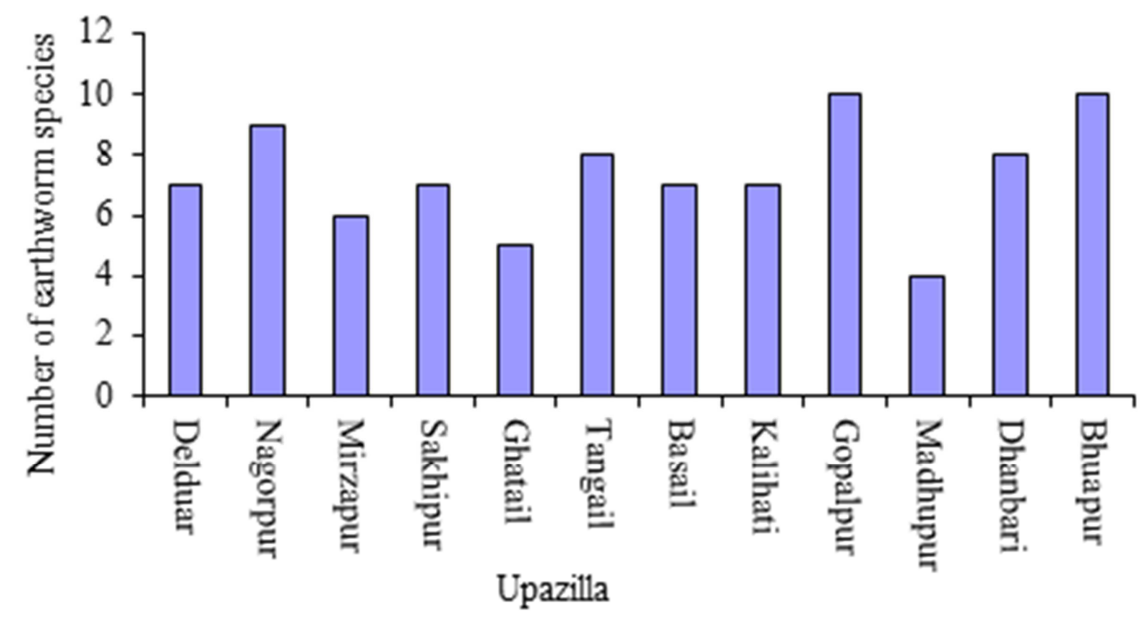

Note: Upazilla=Sub District

Figure 2. Distribution of earthworm species in different areas.

Table 1. The estimated average (Mean $\pm S D$ ) values of soil pH, organic carbon (OC) and nitrogen (N) at the studied in different upazillas in Tangail district of Bangladesh.

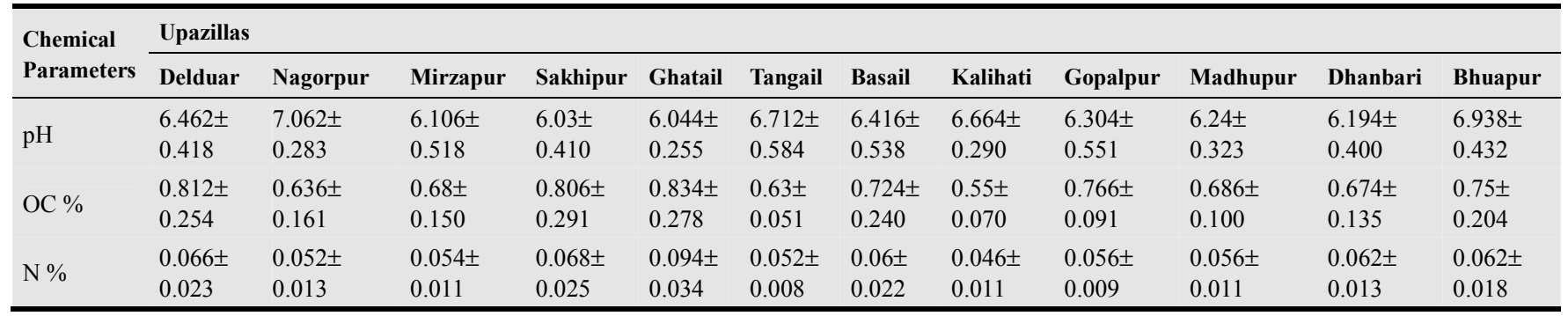

\subsection{Soil pH}

Soil $\mathrm{pH}$ is the negative logarithm of hydrogen ion concentration in soil solution expressed in $\mathrm{g} / \mathrm{l}$. The mean values of soil $\mathrm{pH}$ of different upazilas have been presented in the table 1 . The $\mathrm{pH}$ values of experimented samples ranged from 4.65-7.75 in the homestead garden, 5.30-7.80 in water body, 4.80-7.60 in cultivable land, 4.12-7.80 in fallow land and 4.72-7.60 in steep soil. The recorded $\mathrm{pH}$ value of soil in the study area and effective $\mathrm{pH}$ value on soil fertility (introduced by SRDI Bangladesh 4.5< Mostly Acidic, 4.5-5.5 More Acidic, 5.6-6.5 Slightly Acidic, 6.6-7.3 Neutral, 7.4-8.4 Slightly Alkaline, 8.5-9.0 More Alkaline and >9.0 Mostly 
Alkaline) shows that out of 12 upazila $\mathrm{pH}$ values of 8 upazila are slightly acidic and 4 upazila are neutral. The soil $\mathrm{pH}$ was positively correlated in maximum habitat with the distribution. The minimum average $\mathrm{pH}$ value $(6.03 \pm 0.410)$ is observed in the soil of Sakhipur upazila and the maximum average $\mathrm{pH}$ value $(7.062 \pm 0.283)$ is observed in Nagorpur upazila in Tangail. The $\mathrm{pH}$ value of soil in the study area is slightly acidic but very close to the neutral status. The $\mathrm{pH}$ values are positively correlated with earthworm distribution. The relationship between $\mathrm{pH}$ value of soil and earthworm species distribution in different habitats are presented in the figures (3.a-3.e).

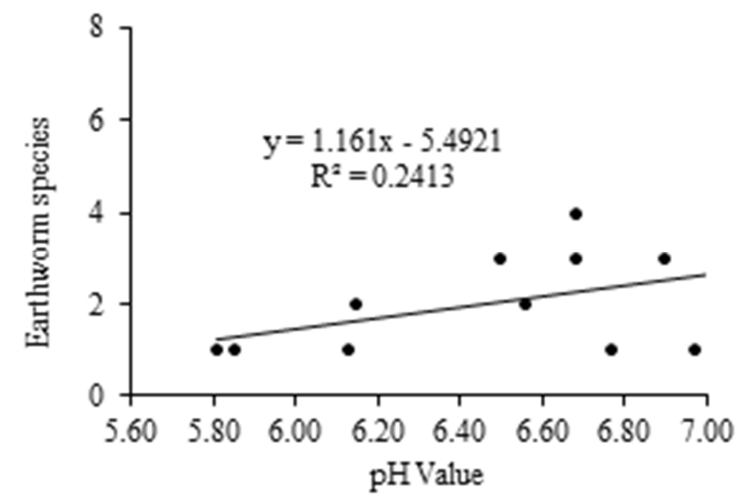

Figure 3.a. Relationship between $p H$ value of soil and earthworm species of homestead garden soil.

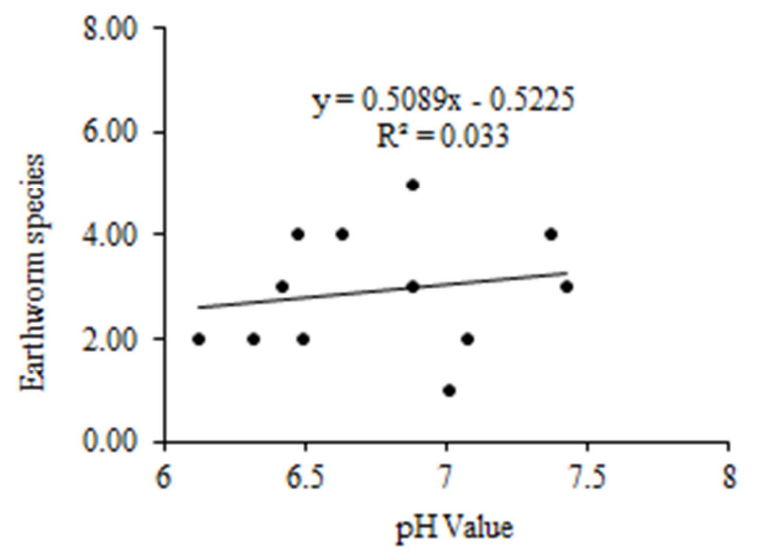

Figure 3.b. Relationship between $p H$ value of soil and earthworm species of waterbody soil.

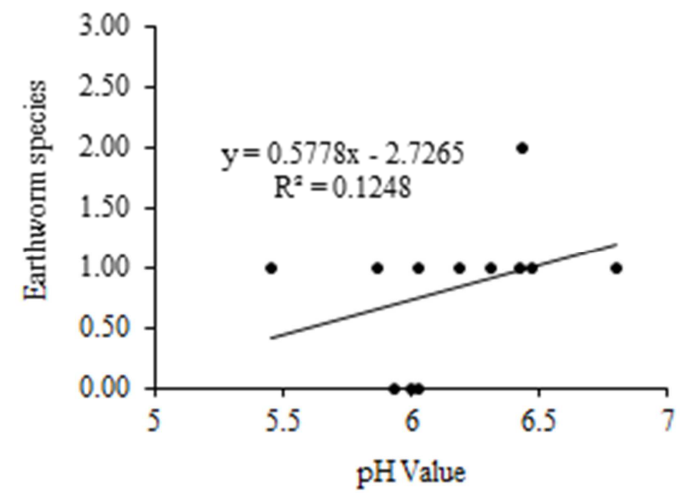

Figure 3.c. Relationship between $\mathrm{pH}$ value of soil and earthworm species of cultivable land soil.

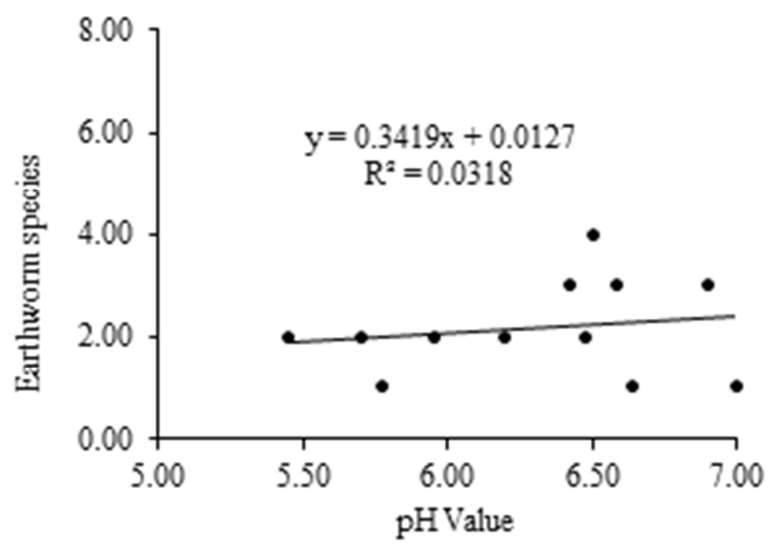

Figure 3.d. Relationship between $p H$ value of soil and earthworm species of fallow land soil.

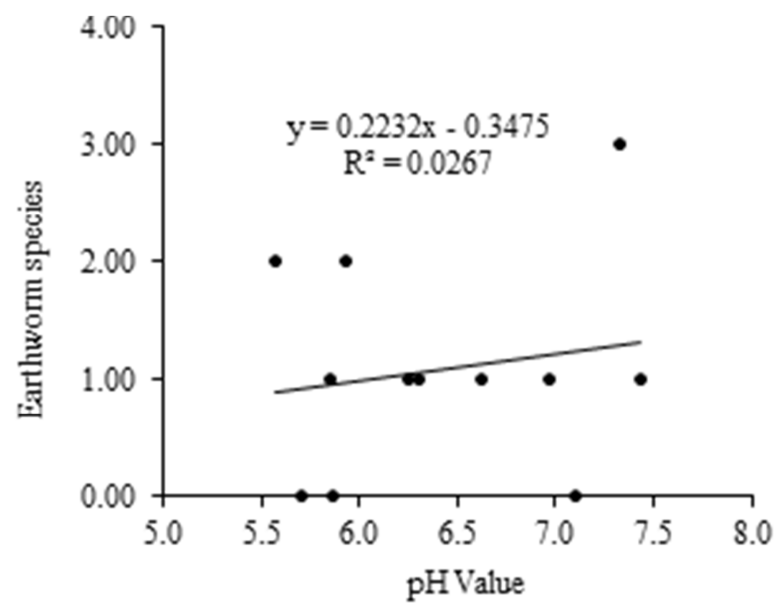

Figure 3.e. Relationship between $\mathrm{pH}$ value of soil and earthworm species of steep soil.

\subsection{Soil Organic Carbon}

Organic carbon (OC) is an important nutrient of soil environment and fertility to grow the plant and productivity. The mean values of soil OC $\%$ of different upazila have been presented in the table 1 . The experimented organic carbon content of different soil samples in the study area ranges from $0.27-1.90 \%$ in the homestead garden, $0.12-1.43 \%$ in $\mathrm{W}$. body, $0.25-1.72 \%$ in cultivable land, $0.15-1.90 \%$ in fallow land and $0.30-1.34 \%$ in steep soil. The recorded OC \% in the study area and effective $\mathrm{OC} \%$ values on soil fertility (introduced by SRDI Bangladesh) show that OC \% content values of all the 12 upazila are under low level marked OC, $1 \%<$. The existing OC status of the soil in the study area is not good at all. It is an alarming state to the agriculture to maintain the soil productivity in the future. Organic carbon is positively correlated with earthworm distribution. The minimum average $\mathrm{OC}$ is recorded in Kalihati upazila $0.55 \pm 0.070(\%)$ and the maximum average OC is recorded in Ghatail upazila $0.834 \pm 0.278(\%)$. The organic carbon is positively correlated with earthworm distribution if the over tilling and other factors do not affect upon them. The relationship between OC \% and earthworm species (distribution) are presented in the figures 4.a-4.e. 


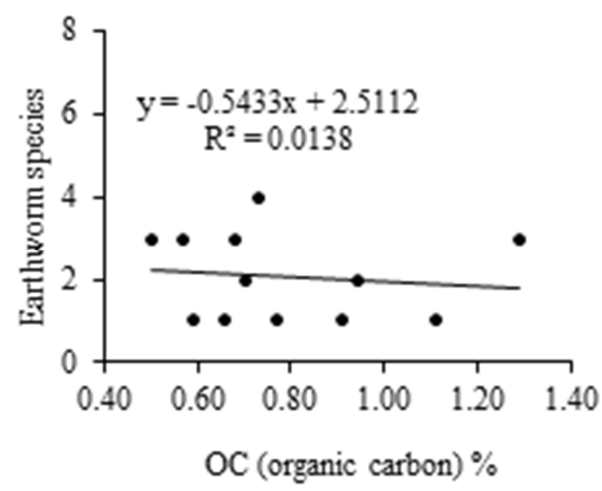

Figure 4.a. Relationship between OC (Organic Carbon) \% of soil and earthworm species of homestead garden soil.

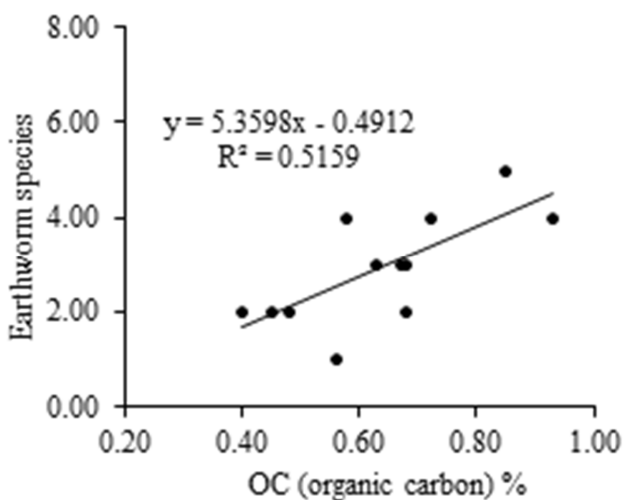

Figure 4.b. Relationship between OC (Organic Carbon) \% of soil and earthworm species of water body soil.

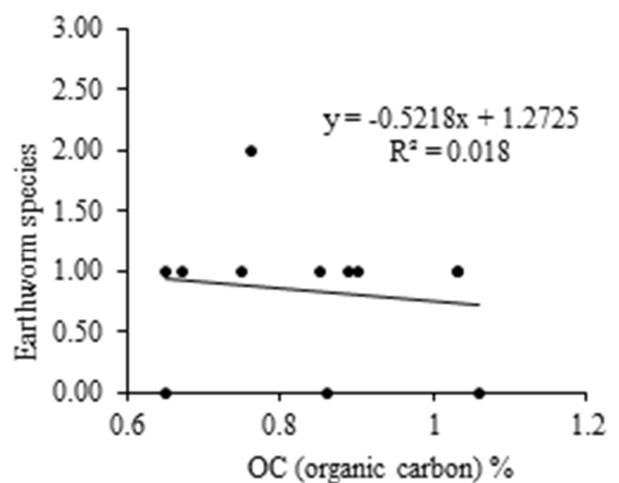

Figure 4.c. Relationship between OC (Organic Carbon) \% of soil and earthworm species of cultivable land soil.

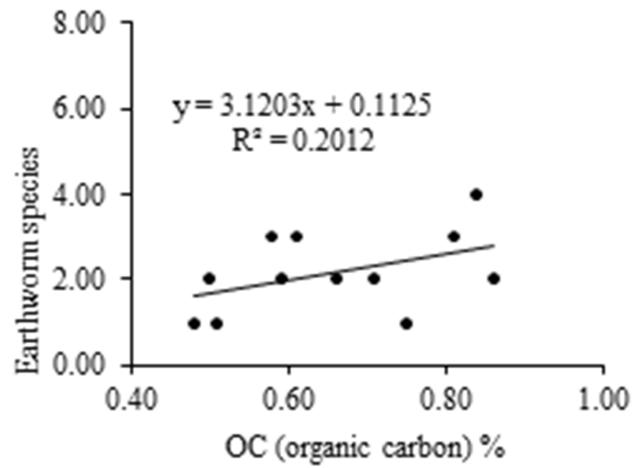

Figure 4.d. Relationship between OC (Organic Carbon) \% of soil and earthworm species of fallow land soil.

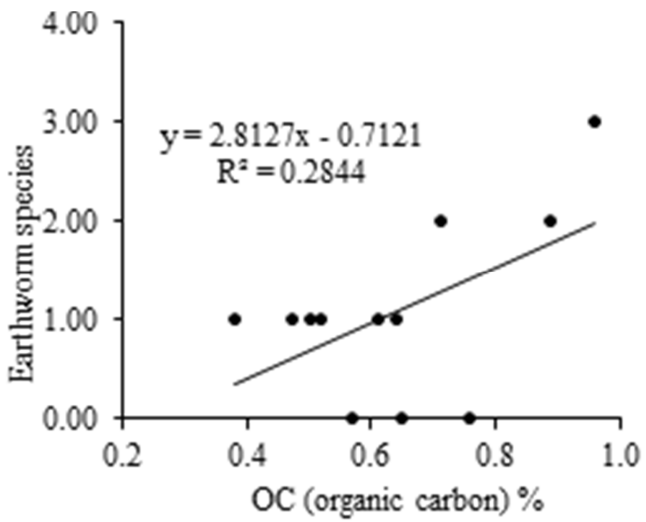

Figure 4.e. Relationship between OC (Organic Carbon) \% of soil and earthworm species of steep soil.

\subsection{Nitrogen}

Nitrogen $(\mathrm{N})$ is a very common and important soil nutrient for plant growth and productivity. Total nitrogen content below the critical level is a threat to floral diversity. So it should be maintained for the betterment of environment. The mean values of soil $\mathrm{N} \%$ of different upazila have been presented in the table 1. Percentage of nitrogen $(\mathrm{N})$ in different soil samples of the study area ranges from $0.03-0.15 \%$ in the homestead garden, $0.01-0.12 \%$ in water body, $0.03-0.14 \%$ in cultivable land, $0.02-0.10 \%$ in fallow land and $0.02-0.11 \%$ in steep soil. The recorded $\mathrm{N} \%$ in the study area and effective $\mathrm{N} \%$ value on soil fertility (introduced by SRDI Bangladesh) show that 11 upazillas' $\mathrm{N} \%$ values of soil are under low level marked $(0.075 \%)$. Medium level marked $(0.076-0.15 \%)$ is found only in Ghatail upazila. The maximum average value of $\mathrm{N}$ $(0.094 \pm 0.034 \%)$ is found in Ghatail and minimum average value of $\mathrm{N}(0.046 \pm 0.011 \%)$ is found in Kalihati upazila. The agriculture depends more to excessive providing of the $\mathrm{N}$ from outsource fertilizer to maintain the soil productivity. Nitrogen is positively correlated with organic carbon. The relationship between $\mathrm{N} \%$ and $\mathrm{OC} \%$ are presented in the figures 5.a-5.e.

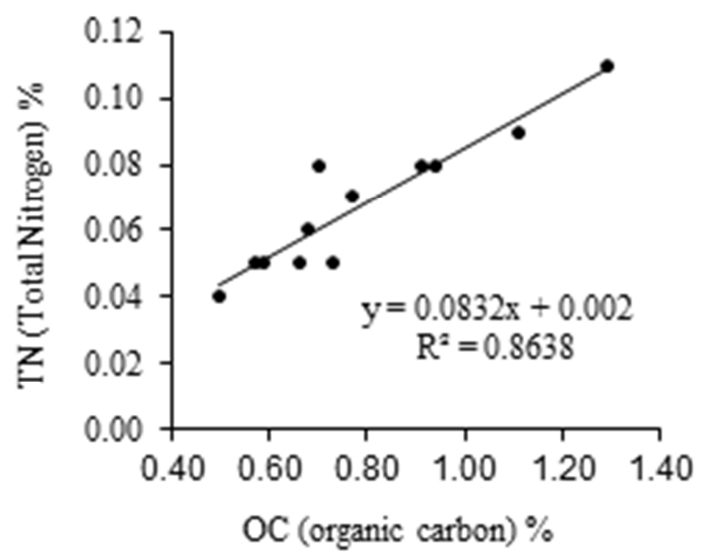

Figure 5.a. Relationship between OC (Organic Carbon) \% and N (Total Nitrogen) of homestead garden soil. 


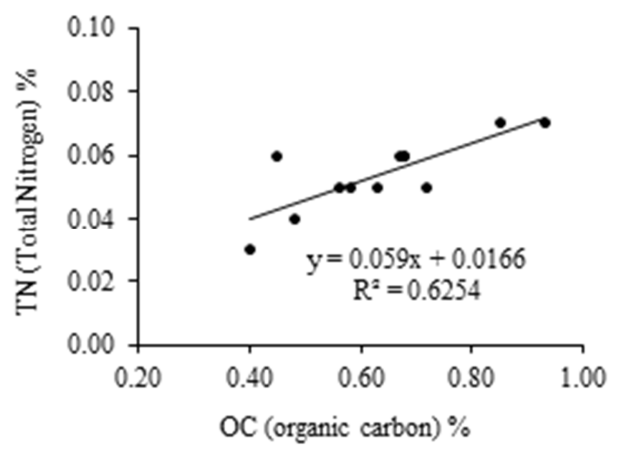

Figure 5.b. Relationship between OC (Organic Carbon) \% and $N$ (Total Nitrogen) of W. body soil.

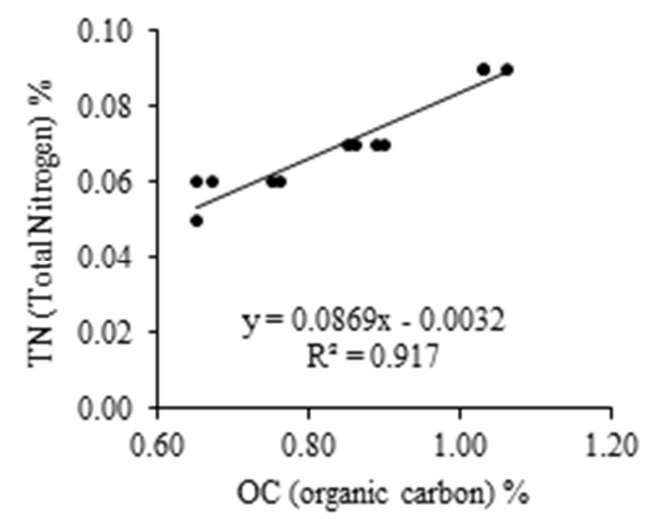

Figure 5.c. Relationship between OC (Organic Carbon) \% and N (Total Nitrogen) of cultivable land soil.

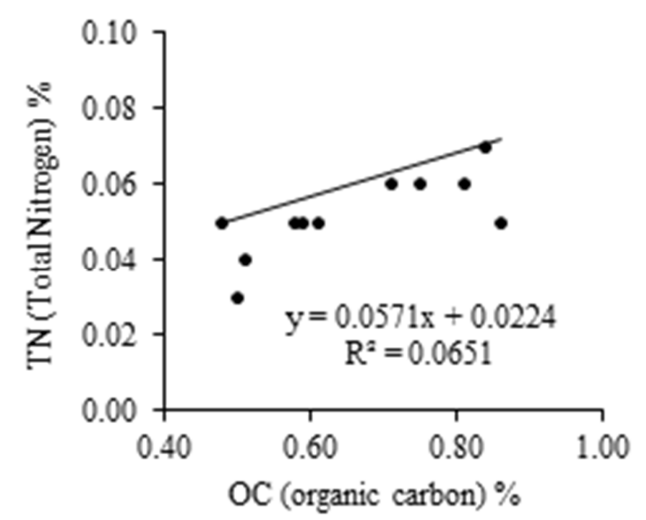

Figure 5.d. Relationship between OC (Organic Carbon) \% and N (Total Nitrogen) of fallow land soil.

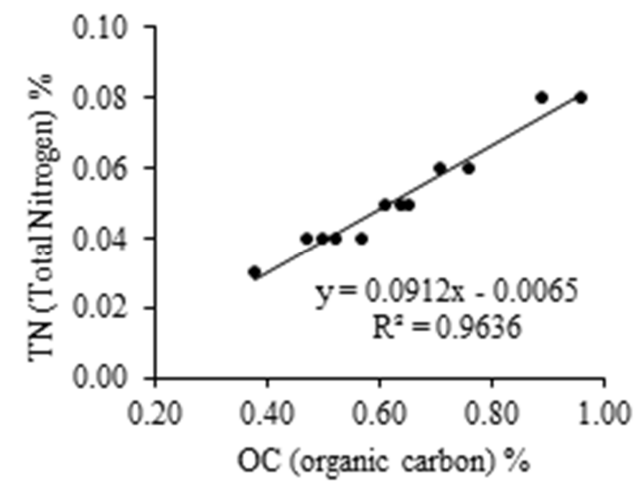

Figure 5.e. Relationship between OC (Organic Carbon) \% and N (Total Nitrogen) of steep soil.

\section{Discussion}

The earthworm is one of the most important members of the soil fauna because they influence the structure, chemical composition and distribution of plant nutrients in soil [11] and[22-23]. The distribution of different earthworm species was studied in various habitats in the study area. D. limella is found in two habitats C. land and F. land habitat, $D$. nepalensis is found in two habitats $\mathrm{C}$. land and $\mathrm{F}$. land habitat. G. tuberosus is found in two habitats W. body and C. land habitat, $P$. corethrurus is found in three habitats W. body, C. land and F. land habitat, $A$. alexandri is found in two habitats H. garden and F. land habitat, L. mauritiiis found two habitats $\mathrm{H}$. garden and W. body habitat, $M$. houlleti is found in a single habitat W. body habitat, $M$. posthuma is found in three habitats $\mathrm{H}$. garden, W. body and F. land habitat, $P$. excavatus is found in two habitats W. body and F. land habitat, P. horai is found in two habitats W. body and C. land habitat, $P$. modestus is found in two habitats in $\mathrm{H}$. garden and $\mathrm{W}$. body habitat, $P$. simalensisis found in two habitats in $\mathrm{H}$. garden and W. body habitat, D. modiglianii is found in two habitats in W. body and C. land habitat, D. saliensis found in two habitats W. body and F. land habitat, E. gigasis found in two habitats in F. land and steep habitat. E. orientalis is found in two habitats in F. land and steep habitat. The highest number of species was observed in W. body habitat, 11 in number. W. body certainly covers the optimum organic matter and other influencing factors. The lowest number of species was observed in steep habitat, 03 in number. Same number of species that was 5 was observed in homestead garden habitat and cultivable land habitat, 9 species were observed in fallow land habitat. The distribution of earthworm species in the cultivable land was not enough. There were 16 species of earthworms recorded: seven species were recorded from Delduar upazila, nine species from Nagorpur, six species from Mirzapur, seven species from Sakhipur, five species from Ghatail, eight species from Tangail, seven species from Basail, seven species from Kalihati, ten species from Gopalpur, four specie from Madhupur, eight species from Dhanbari and ten species from Bhuapur upazila in Tangail district. The highest number of species distribution was observed in Gopalpur and Bhuapur upazila.

An important factor of earthworms' environment is $\mathrm{pH}$. Earthworms are very sensitive to it. Different authors have presented different comfortable $\mathrm{pH}$ range for earthworms as: 5.45 to 8.60 [24] and 6.3 to 8.1 [25]. [26] reported that $\mathrm{pH}$ from 6.5 to 7.5 is suitable in which most soil nutrients are available to plants. The development of compost worm is promoted between a $\mathrm{pH}$ of 7 and 8 [17]. The $\mathrm{pH}$ value slightly acidic to neutral status was well responded by the earthworm in the study area, Tangail district, Bangladesh. The table I (one) shows that the recorded $\mathrm{pH}$ values of the soil of 8 upazila were slightly acidic (5.6-6.5), and 4 are neutral (6.6-7.3) in the scale of SRDI Bangladesh. The average $\mathrm{pH}$ value of soil in the study area is slightly acidic but very close to the neutral status that indicates a good $\mathrm{pH}$ status and the existing $\mathrm{pH}$ value correlates a positive 
relationship with the earthworms' distribution.

The existing OC (organic carbon) status of the soil in the study area is not good at all. The soil of all the upazila shows low level marked OC $(<1 \%)$. Good and productive soil needs more than $3 \%$ OC. In spite of this the minimum OC is recorded in Kalihati upazila $0.55 \%$ and the maximum $\mathrm{OC}$ is recorded in Ghatail upazila $0.83 \%$. Positive correlation exists between $\mathrm{OC}$ and $\mathrm{N}, \mathrm{OC}$ and earthworm distribution. A positive correlation exists between population density and the available soil organic matter, which is one of the important factors influencing earthworm abundance [27].

Nitrogen enters into the soil through earthworms by three main pathways in the form of dead earthworms, in the form of urine as ammonium and urea and in the form of muco proteins secreted by epidermal and intestinal gland cells [28]. Nitrogen $(\mathrm{N}) \%$ value of the soil in the study area and effective $\mathrm{N} \%$ value on soil fertility (introduced by SRDI Bangladesh) show that under low level marked N (0.075\%) content is in 11 upazila. Medium level marked N (0.076$0.15 \%$ ) is found in only in Ghatail upazila. The existing $\mathrm{N}$ status of soil in the study area is in crucially poor status. Nitrogen positively correlates with organic carbon.

The present investigation reveals that $\mathrm{pH}, \mathrm{OC}, \mathrm{N}$, correlate positively with the earthworm distribution. The phenomenon indicates that the casting activity of earthworm has positive impact on physical and chemical properties of soil. It is in accord with [15] that earthworm consumes the organic materials for processing the elements essential for amelioration of soil and plant growth. Large scale for agricultural practices, construction, developmental activities and changes in land use pattern directly affect the composition and population structure of earthworm communities in different agro-climatic regions [29-31]. The earthworm diversity and distribution enhance the biological diversity, soil environment and fertility.

\section{Conclusion and Recommendation}

The earthworm feeds on organic matter along with soil and converts the ingested materials into humus substances within short period and executes them in the nature that increases the soil fertility. So it has a strong claim as beneficial being and better cultivator. Nutrient exhaustion is a threat to food security and to the lives and livelihoods of ever growing people of the country. Extreme tilling of farmland disturbs the earthworm habitation in the field. The distribution of earthworm species has significant impact on Soil $\mathrm{pH}$, organic carbon and nitrogen. The status of earthworm faunal diversity in Tangail district is not poor certainly, but it is needed to conserve ensuring the participation of the common people in this case. Organic manure should be used in the field instead of chemical fertilizer. Chemical fertilizers, insecticide, pesticide, herbicide using should be controlled through organic culture. Over tilling in cultivation should be checked and vermicompost should be more familiar with the farmer. The organism is highly important for soil fertility, ecology and above all environment. Public awareness should be increased to utilize the earthworm in agriculture.

\section{References}

[1] W. Michaelsen, Die geographische Verbreitung der Oligochäten, Berlin. Mukherjee, I. N. and Singh, J. 1986. "A comparison of different quadrate size and extraction methods for estimating earthworm population from tropical soils of Varanasi" In: Proc. Nat. Sem. Org. Waste Utiliz. Vermicomp. Part B: Verms and Vermicomposting, (eds. M. C. Dash; B.K. Senapati \& P. C. Mishra), School of Life Science, 1986, Sambalpur University, Orissa, India. 23-28 pp.

[2] J. Singh, "Habitat preferences of selected Indian earthworm species and their efficiency in reduction of organic materials" 1997, Soil Biology and Biochemistry, vol. 29, pp. 585-588.

[3] S.A. Bennour and G. A. Nair, "Density and biomass and vertical distribution of Aporrecto deacaliginosa (Savigny, 1826) (Oligochaeta, Lumbricidae) in Benghazi, Libya" 1997, Biology of Fertile Soil, vol. 24, pp 102-105.

[4] J. Scullion, and A. Malik, "Earthworm activity affecting organic matter, aggregation and microbial activity in soils restored after open cast mining for coal" 2000, Soil Biology and Biochemistry, vol. 32, 119-126.

[5] G. Tripathi, and P. Bhardwaj, "Earthworm Diversity and Habitat Preferences in Arid Regions of Rajasthan" 2004, Zoos' Print Journal, vol. 19, 7, pp. 1515-1519.

[6] C.A. Edwards, and P.J. Bohlen, "Biology and Ecology of Earthworms" 1996, Chapman \& Hall, London, 380 p.

[7] S.R. Ganihar, "Earthworm distribution with special reference tophysicochemical parameters" 1996, Proceedings of Indian National Science Academy, vol. 62, pp. 11-18.

[8] I. N. Mukherjee, and J. Singh, "A comparison of different quadrate size and extraction methods for estimating earthworm population from tropical soils of Varanasi" In: Proc. Nat.Sem. Org. Waste Utiliz. Vermicomp. Part B: Verms and Vermicomposting, (eds. M.C. Dash; B. K. Senapati \& P. C. Mishra), School of Life Science, 1986, Sambalpur University, Orissa, India. 23-28 pp.

[9] Bangladesh Agricultural Research Council (BARC) "Fertilizer Recommendation Guide" 1997, 25 p.

[10] A. Grappelli, U. Tomati, and G. Palma, "Plant consisting of modular elements for degrading organic wastes by means of earthworms" Patent Entry at Consiglio Nazionale dell Ricerche, Rome (Italy), 1985.

[11] K. E. Lee, "Earthworms: Their Ecology and Relationships with soils and Land use" 1985. Academic Press, Sydney, Australia, 411p.

[12] M.S. Islam, M.S. Amin, and M. N. Anwar, "Integrated soil fertility management in Bangladesh" In: "Proceedings of the Inter-Congress Conference of Commission IV of ISSS on Improving Soil Management for Intensive Cropping in the Tropics and Sub-Tropics", 1992. ed. By Hussain, M.S., Huq, S.M.I., Iqbal, M.A. and Khan, T. H., 147-156 pp.

[13] A. D. Mackay, J.K. Syers, J. A. Springett, and P. E. H. Gregg, "Plant availability of phosphorous in superphosphate and a phosphate rock as influenced by earthworms" 1982, Soil Biol. Biochem., vol. 14, 281-287. 
[14] P. Lavelle, "Earthworm activities and the soil system" 1988 , Biol. Fertile Soils, vol. 6, pp. 237-251.

[15] M.S. Jahan, M.N. Pramanik, M.M Sarker and M.R. Rahman, "Production of earthworm Cast and Its Impact on Soil Properties in Bangladesh" 2003. J. Asiat. Soc. Bangladesh, Sci. vol. 29, 1, pp. 133-142.

[16] T. Lewis, and L. R. Taylor, "Introduction to Experimental Ecology” 1979, Academic Press London, 219 pp.

[17] C.A. Edwards, and J. R. Lofty, "Biology of Earthworms" 1977, 2nd ed., Chapman \& Hall, London, 333 pp.

[18] J. Stephenson, "Fauna of British India (Oligochaeta): Including Ceylon and Burma" 1923. Tailor \& Francis, London, $518 \mathrm{pp}$.

[19] G.E. Gates, "Burmese Earthworms. An introduction to the systematic and biology of Megadrile Oligochaetes with special reference to Southeast Asia" 1972. Trans. Am. Phil. Soc., NS, vol. 62, 7, pp. 1-326.

[20] J.M. Julka, "Fauna of India: Megadrile: Oligochaeta (earthworms) Haplotaxida: Lumbricina; Megascolecoidae: Octochaetidae" Zoological Survey of India, 1988, Calcutta, India, $400 \mathrm{p}$.

[21] S. M. H., Kabir, M, Ahmed, A.T.A., Ahmed, A.K.A. Rahman, Z.U. Ahmed, Z.N.T. Begum, M.A. Hasan and M. Khondker, (eds.). "Encyclopedia of Flora and Fauna of Bangladesh, Vol. 16. Annelida, Echinodermata, Acanthocephala and Minor Phyla" 2009, Asiatic Society of Bangladesh, Dhaka. 232pp.

[22] C. Darwin, "The Formation of Vegetable Mould through the Action of Worms, With Observations of their Habits" 1881, Murray, London, 326pp.
[23] A. Zicsi, "Zootische Einflusse auf die Streuzersetzung in Hainbuchen-Eichenwald Ungarns" 1975, Pedobiologia, vol. 15, pp. 432-438.

[24] H.W. Olson, "The earthworms of Ohio" 1928, Ohio Biol. Surv. Bull., vol. 17, pp. 47-90.

[25] A.C. Evansand W. J. M. L. Guild, "Studies on the relationships between earthworms and soil fertility" 1947, J. Biological Studies in the field. Ann. Appl. Biol., vol. 34 pp. 307-330.

[26] R.V. Tamhane, D.P. Motiramani, Y.P. Bali and R.L. Donahue,"Soils Their Chemistryand Fertility in Tropical Asia"1970, Prentice Hall of Indian Private Limited, New Delhi, P. 29 pp.

[27] P. J. Hendrix, B. R. Mueller and R.R. Bruce, "Abundance and distribution of earthworms in relation to landscape factors on the Georgia Piedmont, USA.” 1992, Soil Biol. Biochem., vol. 24, pp. 1357-61.

[28] K.E. Lee, "The role of soil fauna in nutrient cycling. In: Advances in management and conservation of soil fauna" (eds. G. K. Veeresh, D. Rajagopal \& C.A. Viraktamath), Oxford \& IBH Publishing Co. Pvt. Ltd. 1991, New Delhi, India, pp. 465-472.

[29] E. Blanchart and J. M. Julka, "Influences of forest disturbance on earthworm communities in Western Ghat, South India" 1997, Soil Biology and Biochemistry. Vol. 29, pp. 303-306.

[30] B. Behera, S. Giri, N.C. Dash and B. K. Senapati, "Earthworm bio-indicators of forest land use pattern" 1999, Indian Foresters. 124: 273-281

[31] T. Bhadauria, P.S. Ramakrishnanand K. N. Srivastava, "Diversity and distribution of endemic and exotic earthworms in Biology and Biochemistry" 2000 vol. 32, pp. 2045-2054. 